\title{
FEMALE CHARACTER'S STRUGGLE UPON PATRIARCHY PORTRAYED IN MARY E. WILKINS'S THE REVOLT OF MOTHER
}

\author{
Rini Susilowati ${ }^{1}$ \\ rini.ariyanto12@gmail.com
}

\section{Universitas Muhammadiyah Kotabumi}

\begin{abstract}
Short story as one of literary works can be the reflection of human life and also historical background in which human live in certain time and period. The portrayal of the characters in the short story can describe vividly the life of people in the real life in certain period. This article tries to portray how women in America living under the pressure of patriarchy during 1920s and it is described though female character in Mary E Wilkins's The Revolt of Mother. The struggle of female character in this short story to survive upon the oppression of patriarchy is so touching and inspiring. The author creates such a delicate but tough female character who finally can conquer her husband's absolute privilege which made her to live with suffering for forty years. The female character's suffering in this short story is hoped to be our inspiration to give more appreciation for women, and giving them protection from the violence comes from patriarchy.
\end{abstract}

Key words: female character, short story, patriarchy

Abstrak: cerita pendek adalah salah satu karya sastra yang dapat menjadi refleksi dari kehidupan manusia dan juga latar belakang sejarah tertentu dimana manusia hidup di suatu waktu tertentu dan masa tertentu. Penggambaran karakter yang ada di dalam cerita pendek dapat menggambarkan dengan jelas kehidupan manusia di dunia nyata di suatu periode masa tertentu. Artikel ini mencoba untuk menggambarkan bagaimana wanita di Amerika hidup di bawah tekanan patriarki selama tahun 1920s dan hal ini digambarkan melalui karakter wanita pada cerita pendek karya Mary E. Wilkins berjudul The Revolt of Mother. Perjuangan karakter wanita dalam cerita pendek ini untuk lepas dari tekanan patriarki sangat menyentuh dan menginspirasi. Pengarang cerita ini menciptakan sosok karakter wanita yang lembut namun tangguh yang pada akhirnya dapat mengalahkan hak istimewa mutlak suaminya yang membuat nya hidup menderita selama empat puluh tahun. Penderitaan karakter wanita dalam cerita pendek ini diharapkan menjadi inspirasi untuk memberi penghargaan yang lebih kepada wanita, dan memberi mereka perlindungan dari kekerasan yang berasal dari patriarki.

Kata kunci: karakter wanita, cerita pendek, patriarki

\section{INTRODUCTION}

Characters always attracts the readers' attention anytime they found in literary works written by the authors. One of which is the characters found in short story. The portrayal of characters in short story can represent the main theme of the story, as well as the plot, the symbolism, and even the historical 
background behind the short story itself. Character is someone depicted in the short story through some techniques such as: through the way the character behaves, talks, argues toward something, interact and communicate to other characters and also through the character's stance toward all aspect in the life where the story described. Abrams (as cited in Kharimah, 2017) defined character as someone depicted in a narrative work or dramatic work by analyzing the character's particular moral, intellectual, emotional qualities from what the character says and does (p. 9). Meanwhile, Gordon and Kuenher (as cited in Kharimah, 2017) state, "character is a person created a work of fiction" (p. 9).

The characters on the short story can be protagonist, antagonist, major character, minor character, or can be flat character and round character. For those types of characters, the character can be presented as male character and it can be female character depend on how the author want to describe it based on its gender. Female character often found in short story and this character becomes the center of story itself or in certain occasion having the same important role compared to other major character in the short story. Through the portrayal of females' character, we obtain vivid idea of what short story tells us and even we can get the idea of what exact event and phenomenon really happen during the historical background in which the short story written. Kusch (2016) states, "literature encapsulates human experience and records the messy, painful, triumphant, and sublime realities of the passage of humans through our world" (p. 1). In addition, Kusch (2016) also states, "literature offers us the human life in totalnot reduced-with its inconsistent logic morality, and identity on full display" (p. 1). Therefore, reading short story can enrich our knowledge related to how human perceive their life with all of its problem and suffering and how human survive upon it. Besides, short story can be such mirror for certain events happen in the history of human life so that the readers can obtain useful new knowledge. According to Kusch (2016) literature teaches us about knowledge, moral and social lesson, new ideas, records revolution, cultural values and also best and worst of selves (p. 1). Therefore, short story can give us clear description of how female characters in it represent the women in the real life facing their life.

A lot of short stories exist, and they come from authors all over the world and the readers can learn a lot of things by reading it. Among female characters found in many 
short stories written by the authors in the world is the female character portrayed in Mary E. Wilkins' The Revolt of Mother. The female character represents the women at the past struggling to have their rights in some aspects of the life. Mary E. Wilkins portrayed how patriarchy still dominant in the life of people living in rural area where agriculture and traditional life become the way of life and man or father is the breadwinner for the whole members of the family.

Patriarchy issued in Mary E. Wilkins's The Revolt of Mother deals with the event in which men are the breadwinner and become dominant in their family. Women at the time the short stories written are supposed to be oppressed and subordinated because of their incapability to earn money, their weakness on voicing their minds, and the strict stereotype of the society that men should have the highest authority upon their family as well as in the society covering some important domains in the life. Hernett (2009) explains, "because government concentrated primarily on the preservation and capitalism of the big business, "women's concern" of health care and individual human rights were often disregarded" (p. 29). The condition described previously in line with the condition of women in America around 1920s where the issue of patriarchy was still dominant in some aspects of life. Meanwhile, the female character portrayed in the short story mentioned before being the reflection of how women in some decades ago being inferior because their position in the family. They are under men's or husband's absolute authority because their weakness on fulfilling their needs and money as well as their role only on domestic labor. Kennedy (as cited in Pamungkas, Suwandi, and Rohmadi, 2019) states, "events in short story are dealt with in such a way to fit the reality of life" (p. 187). That explanation strengthens the relevance of historical background exposed in the short story the writer discusses in this article to the real fact and condition of women during 1920s in America. As further discussion concerning to the issue of patriarchy portrayed in the short story as the reflection of past decades condition, the writer will elaborate more on the concept of character and patriarchy, and how female character in the short story trying to struggle upon the patriarchy.

\section{Female Character's Struggle Upon Patriarchy Portrayed in Mary E. Wilkins's The Revolt of Mother}

The discussion about character should precede the discussion about portrayal of female character's struggle upon patriarchy. It is hoped that by discussing concept of 
character firstly, the readers will understand better what is character and how character in this short story interact and specifically how female character in this short story struggling for her triumph upon patriarchy which oppresses her for forty years.

\section{The Concept of Character}

Character is the person described in the story by using direct presentation or can be through indirect presentation. Abrams (as cited in Patmarinanta and Ernawati, 2016) states, "character is people who are appeared in a narrative prose or novel and it is interpreted by the readers as a person who has morality quality and certain tendency such as being expressed in what they say and what they do" (p. 27). Character becomes one of important elements in short story because by analyzing the character the readers will have understanding of the main theme of the story. Besides, character's existence can create the atmosphere of the story to be more interesting. Dickinson (as cited in Patmarinanta and Ernawati, 2016) explains, "character is the person who can contribute to a story in several ways" (p. 27). Meanwhile, in line with the significance of character's existence in a short story, Bennet and Royle (as cited in Putri, 2017) emphasize that characters are the life of literature and become the object of the readers' curiosity and fascination, affection and dislike, admiration and condemnation (p. 4). The character's action and speech act will reflect his or her personality on the short story and can be the determination for the type of the story.

Character described in the short story through characterization. Characterization related to the process in which the author creating the character and shaping the character's personality traits through direct and indirect presentation. Bennet and Royle (as cited in Putri, 2017) define characterization as the process done by author in revealing his character in a work of fiction or in another word characterization is the method of character portrayal (p. 3). The author using direct presentation of characterization when he describes clearly and directly what a character is look like through narrator's description, other character or by the characters himself. Meanwhile, indirect presentation of characterization done through character's speech, thoughts, action, and look.

Relating to character in short story, there are some types of characters presented. The various characters portrayed in the short story will create lively situation so that the readers will experience the real condition in 
everyday life. There are flat character and static character, and there are round character and dynamic character. Flat character is a minor character in a work of fiction who does not change at the whole plot of the story. According to Wiehardt (as cited in Saraswati, 2019) flat characters are minor character in a work of fiction who do not undergo substantial change or growth in the course of a story. A static character is a character who does not change and this character appear more than once in some occasion (p.22).

The other character are round character and dynamic character. Round character can be multidimensional and complex, and this character has quite enough role to the plot of the story. Round character does not have to be main character. The next is dynamic character. This character is the opposite of static character. Having the same characteristic compared to round characteristic, dynamic character also has some change in the story. Instead of some characters described based on the change undergo by the characters, authors of fiction works also use protagonist and antagonist character to portray characters based on the quality of the characters' behavior. Protagonist is the main character of the fiction works and receive the sympathy from the readers. Antagonist tend to be the opposite of protagonist. This character known as the bed guy in fiction works and this character has strong ambition to thwart what protagonist want to do in his life. The last is the type of character based on the significance in the fiction works. There are major character and minor character. Major character is the protagonist and having important influence to the plot of the story. This character appears almost in all of the occasion of the story. The opposite is minor character. Minor character is seldom appear in the story or the having less importance in the story.

\section{The Concept of Patriarchy}

Patriarchy is kind of social structure in which men are considered as having more power and higher position than women. Tong (as cited in Govanda, 2018) states, "patriarchal society uses certain fact that male and female as the basis for constructing a set of masculine and feminine gender identities and behaviors that serve the empower men disempower women" (p. 14). Moreover, Cejka and Eagly; Deaux and Lewis (as cited in Denmark and Paludi, 2008) state, "men are viewed as leaders, financial providers and head of household, and women are seen as caregivers who shop, tend the house and provide emotional support" ( $\mathrm{p}$. 207). Patriarchy position women as inferior 
because of their position in the family who tend to be the people who handle domestic labor and commonly not earning money for the family's needs. Djajanegara (as cited in Pamungkas, Suwandi, and Rohmadi, 2019) explain that women are positioned in the camps / realm of domestic work at home due to patriarchy culture and as the impact is women being subordinated (p. 189). Although not all women in the world not earning money for their family's needs, patriarchy often found in certain time, cases, areas, and time period. Even though it still exists in the society, the impact of patriarchy is not too extreme compared to some decades ago.

There are some definitions of patriarchy and one of which is according to Pierik (as cited in Ramadhan, 2019) the original word of patriarchy comes from Greek word which means "father who rules the family" (p. 1). Meanwhile, Sultana (as cited in Ramadhan, 2019) state that the literal meaning of patriarchy is the rule of father in which men dominated included in junior male, children, slaves, and also servants, of all under the rule of dominant male (p. 1). In relation to definition of patriarchy, Johannsdottir and Sultana (as cited in Ramadhan, 2019) explain, "patriarchy as a system of social structure and practice in which men dominate, oppress and exploit women" (p. 1). In a brief word patriarchy is men domination upon the family members especially to women where women and other family members loose their rights to voiced their mind.

Patriarchy exists in human life because men considered as the one who responsible to fulfill all of family's needs. Men are having capability to be the breadwinner and the backbone of their family. This fact pushes men to be the savior of their family by providing physical and emotional need of the family as well as spiritual need and it cannot be changed since it is a destiny. Parsons and Balles (as cited in Copenhaver, 2002) explain that it is quite safe to say that the role of adult female not only primarily related to internal family affairs as wife, mother and the manager of the household, while the role of adult male is predominantly anchored the world of occupational, in his job and through it by his status- giving and income-earning for the family (p. 27). Because of that reason men should be really respected and obeyed. Men have strong physically built body which support them to have ability to work hard and earn more money than women. Tong (as cited in Pamungkas, Suwandi, and Rohmadi, 2019) state that society believes that women have less physical and intellectual ability than 
men, society tend to distinguish women in academia, forums, and markets. Meanwhile, women commonly responsible for domestic labor at home (p. 186). Higgins (as cited in Ramadhan, 2019) explains, "men control women's live and take the benefit materially from patriarchy. Most property and other productive resources are controlled by men. It is because women still do most of domestic labor" (p. 21). It is clear that patriarchy has been the reason for men to dominate the family members in their family.

Men are considered to have rationale thoughts and tend to think logically instead of using their emotional and feeling. That is why men tend to be considered as stronger in facing problems in their life. This fact makes the men to have stereotype that they have higher position, authority and rights to voiced their argument, mind and will toward something. This phenomenon then creates the patriarchy in many aspects of human life. The act influenced by patriarchy can be found in some domains such as at home, the workplaces, social services and other public areas. Johannsdottir; Thompson; Peirik (as cited in Ramadhan, 2019) state that patriarchy has at least 6 structures which are patriarchal relations in household, patriarchal relations in paid work, patriarchal relations in state, male violence, patriarchal relations in sexuality, and patriarchal relations in culture (p. 2). The obvious example of some patriarchal structures occurred in human life will be discussed further in next part.

Johannasdottir (as cited in Ramadhan, 2019) states, "women traditionally are granted worse jobs" (p. 21). Meanwhile, Higgins (as cited in Ramadhan, 2019) states, "a legal right to equal pay has not resulted in the eradication of the gender pay gap" (p. 21). This thing above showing us that patriarchy still oppress women in the workplaces although there is no doubt that there are also women all over the world who have obtained worthy and good salary. The other phenomenon of patriarchy suffered by women when they mistreated by violence done by men. A lot of violence often experienced by women without fair problem solving. Ragasatiwi (as cited in Ramadhan, 2019) explain that there are still a lot of violence upon women done by men without punishment (p. 22). In addition to the fact related to the existence of patriarchy which brings impact to women is women's participation in local governance. Ostman et.al (as cited in Khan, 2018) investigated that the women's role in local governance is lower than men and the reason behind the low contribution is the culture, religion, and injustice against, low economic empower- 
ment, low self-confidence, low educational level and excessive marital obligation (p.12). The description explained previously showing that patriarchy suffered by women in some domains of human life, not only at home but also in some public areas.

Patriarchy cannot be avoided to be occurred since men are predestined to be the leaders at home, institutional and governmental offices, various organization and other forms formal and informal activity. The thing that should be concerned is how to avoid patriarchy to oppress women so that they can live in a worthy live, respected, being honored and having physical and emotional nurture from the family and from society. In order to have clear description of how patriarchy occur toward women and how they survive upon it, the next part of the article will portray how female character from this story struggling to safe their life from the oppression of patriarchy.

\section{Female Character's Struggle Upon Patriarchy Portrayed in Mary E. Wilkins's The Revolt of Mother}

Mary E. Wilkins's The Revolt of Mother is one of short story attracted readers' attention because of its touching moments where mother who is Sarah Penn struggling to have a worthy life after 40 years living under the oppression of patriarchy comes from her husband. Her husband is Adoniram Penn. Sarah and Adoniram living in rural area where they count on agriculture and the farm to support their life. They have one daughter Nanny Penn and one son Sammy Penn. They live in a simple life and stay in a small old house for a long time.

They were in the barn, standing before the wide open doors. The spring air, full of the smell of growing grass and unseen blossoms, came in their faces. The deep yard in front was littered with farm wagons and piles of the wood; on the edges, close to the fence and the house, the grass was a vivid green, and there were some dandelions (Wilkins, 1891, p.1).

Some rooms of their house are also pathetic.

It seems the family members deserve to have better house and better living because Adoniram Penn can earn more money compared to 40 years ago at the time the story written.

Sarah Penn went across the room as though it were a tragic stage. She flung open a door and disclosed a tiny bedroom, only large enough for a bed and bureau, with a path between (Wilkins, 1891, p.7).

The condition of the bedrooms of their daughter and son are also pathetic and Sarah Penn thinks that their children deserve to get a better room to sleep. 
She threw open another door. A narrow crooked flight of stairs wound upward from it. "There, father, "said she, "I want you to look at the stairs that go up to them two unfinished chambers that are all the places our son an' daughter have had to sleep in all their lives. There ain't a prettier girl in town nor a more ladylike one than Nanny, an' that's the place she has to sleep in. It ain't so warm an' tight" (Wilkins, 1891, p. 7).

That condition triggers Sarah Penn to pursue a more worthy life for her and her children since her husband have promised her forty years ago to build a new house for them.

- the digging of the cellar of the new barn in the place where Adoniram forty years ago had promised her their new house should stand (Wilkins, 1891, p. $5)$.

Contrary to his promise, Adoniram Penn will build a new barn in the field where he promises for a new house to stand. Tragically he does not talk about it to his wife by asking his wife's agreement. It disappoints Sarah Penn and she thinks that her husband does not care to his family's comfort. She spends forty years to do all of her domestic responsibility at home without complaining. She really respects her husband and she does not sue for wealth in their life. The husband's plan to build new barn for the farm animals instead of building the worthy house for them to live in really hurts her feeling. Moreover, it becomes the triggers for her to struggle for obtaining what her husband had promised her in order to live in worthy life. The conversation below showing how she tries to remind her husband about his plan to build new barn.

$$
\begin{aligned}
& \text { "father!" } \\
& \text { "what is it?" } \\
& \text { "what are them men diggin' over there } \\
& \text { in the field for?" (Wilkins, 1891, p. 1) }
\end{aligned}
$$

Adoniram Penn does not respond to his wife's question by giving wise explanation. He just says something which reflects that it is his authority to decide everything important in their house.

"I wish you'd go into the house, mother, an' 'tend to your own affairs," the old man said then. He ran his words together, and his speech was almost as inarticulate as a growl (Wilkins, 1891, p. 1).

That statement showing that Adoniram declares his authority as the leader in their house and nobody can interrupt his decision. His words literally point that his decision is his own business, his wife cannot intervene him to change his mind. Domestic labour is the only thing managed by his wife not about occupational matters and other things. It shows how powerless is his wife in front of her husband. Giora (2002) states, "given women's powerless social status, women may find it difficult to substantiate their own perspective" (p.334). Adoniram having 
principle about gender that woman will not have the same opportunity to decide something, that woman should not have equality to voiced her argument. This is in line with the theory of Gender in the family. Risman (as cited in Gentry, Commuri, and Jun, 2003) states, "doing gender means creating differences" (p. 2). In line with that theory, Danields \& Kynaston (as cited in Gentry, Commuri, and Jun, 2003) state, "doing gender implies legitimatizing inequality, as what is female in patriarchal society is devalued" (p. 2). That theory strengthen that Adoniram has point of view that the chance of his wife to argue will not be equal compare to his and its because of gender matter at the house.

Adoniram Penn shows the hardness of heart that nobody can influence him or intimidate him to change his mind and decision. What ideal condition for him is all family members should respect to his opinion and decision. Based on theory of gender it deals with the concept that men tend to be influencers and women are non- influencers. Jacobson (as cited in Gentry, Commuri, and Jun, 2003) states," we would expect that men would attempt to avoid change to protect their positions, or will withdraw to any attempts to get them to change" (p. 7). In addition, Spiro (as cited in Gentry, Commuri, and Jun, 2003) state that the influence strategy used by husbands and wives to solve disagreement concerning to the principle that women are more likely to be non-influencers or emotional influencers and men slightly more like to be "light" or "subtle" influencers (p. 7). The conversation below showing us that Adoniram Penn trying hard to keep his status quo and he does not want to compromise to his wife.

"I want to know what you're buildin' that new barn for, father?"

"I ain't got nothin' to say about it." It can't be you think you need another barn?"

I tell ye I ain't got nothin' to say about it, mother; an' I ain't goin' to say nothin'."

Be you goin' to buy more cows?"

Adoniram did not reply; he shut his mouth tight (Wilkins, 1891, p. 6-7).

Adoniram's statement reflect his stubbornness and he emphasizing to his wife that he gets the status quo at home. Rausch et al. (as cited in Gentry, Commuri, and Jun, 2003) states, "men attempts to keep a decision on a track as long as it does not upset their feelings and disturb the status quo" (p. 8). Adoniram Penn does not want to give little chance for his wife to interrupt his mind even just by saying something which can open the opportunity for his wife to debate him. By saying only"I tell ye I ain't got nothin' to say 
about it, mother; an' I ani't goin' to say nothin" adoniram create the wall between him and his wife. His silence only such a shield for him to strengthen his power as leader and influencer at home. Whisman and Jacobson (as cited in Gentry, Commuri and Jun, 2003) state that the power and influence from men do not come only from talk and persuasion but also come from not listening and not saying anything to what one's partner is saying (p. 8). Men who think that they have absolute status quo at home will have a lot of effort to defend themselves from being intervened by their wife. In this case, Adoniram Penn choosing to protect his status quo by avoid his wife to suggest something to him by keeping silence and only by saying "I ain't got nothin' to say".

Sarah Penn herself has passed forty years to subserve to her husband without complaining that she lives in unworthy life and unworthy home. Nevertheless, her suffering as well as their children's suffering have triggered her to fight against patriarchy upon them. She does not want to surrender to the unfairness that she feels and trying to get justice for her and for children. Once she starts the conversation again to her husband in order to persuade her husband to change his mind. Sarah Penn still speaks politely and respecting her husband although Adoniram
Penn has disappointed her. It shows that she appreciates her husband's privilege at home and she does not want to harm her relationship with her husband. Acccording to Commuri and Risman (as cited in Gentry, Commuri and Jun, 2003) women do gender in a way that they support men's privilege although they have overcome the oppression and institutional barriers upon them from other domains (p. 2). The statement literally mean that women will respect men's privilege although they have been in better condition than the previous one. In this case, Sarah Penn still showing the same respect when she starts to ask her husband again about his plan to build a new barn.

"I know you be, as well as I want. Now, father look here"- Sarah Penn has not sat down; she stood before her husband in the humble fashion of a scripture woman - 'I'm goin' to talk real plain to you; I never have since I married you, but I'm goin' to talk now. I ain't never complained, an' I ain't goin' to complain now, but I'm goin' to talk plain (Wilkins, 1891, p. 7).

Sarah Penn speaks so carefully that she does not want to hurt her husband's feeling. She satirizes her husband that she lives unworthy for forty years without complaining. She says it without anger but her voice sounds really tough.

Sarah Penn went back and stood before her husband. "now, father," said she, "I want to know if you're doing right an' 
according to what you profess. Here, when we was married, forty years ago, you promised me faithful that we should have a new house built in that lot over in the field before the year was out. You said you had money enough, an' you've been makin' more money, an' I've been savin' of it for you ever since, an' you ain't built no house yet. You've built sheds an' cow-houses an' one new barn, an' now you're goin' to build another (Wilkins, 1891, p. 7).

Adoniram Penn does not care to what his wife saying he just say that he has to continue his work. Working is everything for him, but nurturing his family is something which is hard for him to do.

“father, ain't you got nothin' to say ? said Mrs. Penn.

"I've got to go off after that load of gravel. I can't stan' here talkin' all day."

"father, won't you think it over, an' have a house built there instead of a barn?"

I ain't got nothin' to say."

Adoniram shuffled out. Mrs.Penn went into her bedroom. When she came out, her eyes were red.

Sarah Penn is extremely disappointed toward her husband and once her husband goes away for her work business, she dares herself to move all their goods and stuffs to the new barn.

During the next few hours a feat was performed by this simple, pious New England mother which was equal in its way to Wolfe's storming of the Heights of Abraham. It took no more genius and audacity of bravery for Wolfe to cheer his wondering soldiers up those steep precipices, under the sleeping eyes of the enemy, than for Sarah Penn, at the heads of her children, to move all their little households goods into the new barn while her husband was away (Wilkins, 1891, p. 12-13).

Sarah Penn dares herself to end her suffering by having her final effort to reach her dream living in worthy house when her husband going for his business.

At five o'clock in the afternoon the little house in which the Penns had lived for forty years had emptied itself into the new barn (Wilkins, 1891, p. 13).

After they vacate the house finally $\mathrm{Mr}$. Adoniram arrive at home and he is shocked to see the house that has been living for forty years has been emptied.

Adoniram stared at the group. "What on airth you all down here for?" said he. "what's the matter over to the house?"

We've come here to live, father," said Sammy. His shrill voice quavered out bravely.

"what" - Adoniram sniffed. His old bristling face was pale and frightened. "what on airth does this mean, mother?" he gasped (Wilkins, 1981, p. $15)$.

Mrs. Penn reacts toward her husband and explain to him politely about this thing.

The house wa'n't fit for us to live in any longer, an' I made up my mind I wa'n't goin' to stay there. I've done my duty by you for forty years, an' I'm goin' to 
do it now; but I'm goin' to live here. You've got to put in some windows and partitions; an' you'll have to buy some furniture (Wilkins, 1891, p. 16).

Adoniram Penn is shocked, but there is no words come from him. He is shocked because of his wife's rebellion and bravery to protest against his decision. He loses his energy to be angry although his pride as the head of the family is humiliated. His last word to his wife at the end of the short story tells the readers indirectly that he surrenders to the new condition, and he feels guilty to his wife because he denies his promise to his wife and let her lives unworthy for forty years. Finally, Sarah Penn gets her triumph although she should pay much for it by live her life patiently living under her husband's authority for forty years. She starts a new beginning in her life by living in the new house that she longed for a long time. We get the value that patriarchy can be defeated by patience, rigidity, and bravery.

\section{CONCLUSION}

Patriarchy will always exist in human life and it will linger in society although it has appeared some decades ago. The influence of patriarchy has been extremely felt by women from some decades ago since a lot of women at that time still depend on men much. The domestic labour, incapability to earn money, lack of chance to voiced argument, and probably lack of education become the triggers of women's suffering because of patriarchy. Men's privilege should not be banned at home or other formal and informal domains, but the important thing is concerning to how to avoid women become the victims of patriarchy. Men are predestined to be the leaders and to be the heads of the family, and we cannot deny that fact. Thing that should be struggled is how to treat women kindly and tenderly by respecting all their rights. Women should be honored because men cannot stand on their feet without women existence at home and other places where they should be.

\section{REFERENCE}

Copenhaver, B. B. The Portrayal of Gender and A Description of Gender Roles in Selected American Modern and Postmodern Plays. A Dissertation. East Tennessee State University.

Denmark, F. 1. \& Paludi, M. A. (2008). Psychology of Women: A Handbook of Issues and Theories. Florence: Preager. 
Gentry, J. W., Commuri, S. \& Jun, S. (2003). Review of literature on gender in the family. Academy of Marketing Science Review. Vol.2003, 1, 1-18.

Giora, R. (2002). Theorizing Gender Feminist Awareness and Language Change. Amsterdam: John Benjamins Publishing Company.

Govanda, J.Y. (2018). Elisa's Resistance in John Steinbeck's The Chrysanthemums: A Feminist Analysis. Undergraduate Thesis. Universitas Sanata Dharma.

Hernett, K. A. (2009). Appearing Modern: Women's Body, Beauty, and Power in 1920s America. A thesis. Boston College University.

Khan, N. (2018). Critical review of past literature on gender inequality in the world. Research on Humanities and Social Science. Vol.8, 13, 11-26.

Kharimah, V. M. I. (2017). The Main Character's Resistance to Patriarchal Ideology in A Golden Web Novel. A thesis. State Islamic University of Syarif Hidayatullah.

Kusch, C. (2016). Literary Analysis the Basics. New York: Routledge.

Pamungkas, S. A., Suwandi, S., \& Rohmadi, M. (2019). Subordination of women in short story in kompas newspaper. Budapest International research and Critics Institute-Journal. Vol.2, 2, 186-194.

Patmarinanta, A. \& Ernawati, P. (2016). A study on characterization of the main character in "The fault in our stars". Research in English and Education, vol.1, 1, 26-33.

Putri, C. (2017). The Characterization of The Main Character in Gone Girl Film. A Thesis. State University of Medan.

Ramadhan, M. A. A. (2019). The Main Characters' Efforts Against Patriarchy Practices in Arundhati Roy's The God of Small Things. Universitas Islam Negeri Maulana Malik Ibrahim.

Saraswati, K.P. (2019). Analysis of Characters and Characterization in The Compilation of Malay Poetry "Mirror". A Thesis. Universitas Negeri Semarang. 